\title{
Correction to: Scanning electron microscopic observation of the in vitro cultured protozoan, Perkinsus olseni, isolated from the Manila clam, Ruditapes philippinarum
}

Dinesh Gajamange ${ }^{1,2}$, Seung-Hyeon Kim ${ }^{1}$, Kwang-Sik Choi ${ }^{3}$, Carlos Azevedo ${ }^{4}$ and Kyung-II Park ${ }^{1 *}$

\section{Correction to: BMC Microbiol (2020) 20:238 \\ https://doi.org/10.1186/s12866-020-01926-0}

Following publication of the original article [1], we were notified of an error in Fig. 2. Correct Fig. 2 is presented below, providing clearer morphological information about the pathogen.

\begin{abstract}
Author details
'Department of Aquatic Life Medicine, College of Ocean Science and Technology, Kunsan National University, 558 Daehakno, Gunsan 54150, Republic of Korea. ${ }^{2}$ Present address: The Open University of Sri Lanka, Regional Centre, Matara, Sri Lanka. ${ }^{3}$ School of Marine Biomedical Sciences, College of Ocean Sciences, Jeju National University, 102 Jejudaehakno, Jeju 63243, Republic of Korea. ${ }^{4}$ Laboratory of Cell Biology, Institute of Biomedical Sciences, University of Porto, Porto, Portugal.
\end{abstract}

Published online: 18 September 2020

\section{Reference}

1. Gajamange D, et al. Scanning electron microscopic observation of the in vitro cultured protozoan, Perkinsus olseni, isolated from the Manila clam, Ruditapes philippinarum. BMC Microbiol. 2020;20:238. https://doi.org/10. 1186/s12866-020-01926-0.

\footnotetext{
The original article can be found online at https://doi.org/10.1186/s12866020-01926-0.

* Correspondence: kipark@kunsan.ac.kr

'Department of Aquatic Life Medicine, College of Ocean Science and Technology, Kunsan National University, 558 Daehakno, Gunsan 54150, Republic of Korea

Full list of author information is available at the end of the article
}

(C) The Author(s). 2020 Open Access This article is licensed under a Creative Commons Attribution 4.0 International License, which permits use, sharing, adaptation, distribution and reproduction in any medium or format, as long as you give appropriate credit to the original author(s) and the source, provide a link to the Creative Commons licence, and indicate if changes were made. The images or other third party material in this article are included in the article's Creative Commons licence, unless indicated otherwise in a credit line to the material. If material is not included in the article's Creative Commons licence and your intended use is not permitted by statutory regulation or exceeds the permitted use, you will need to obtain permission directly from the copyright holder. To view a copy of this licence, visit http://creativecommons.org/licenses/by/4.0/ The Creative Commons Public Domain Dedication waiver (http://creativecommons.org/publicdomain/zero/1.0/) applies to the data made available in this article, unless otherwise stated in a credit line to the data. 

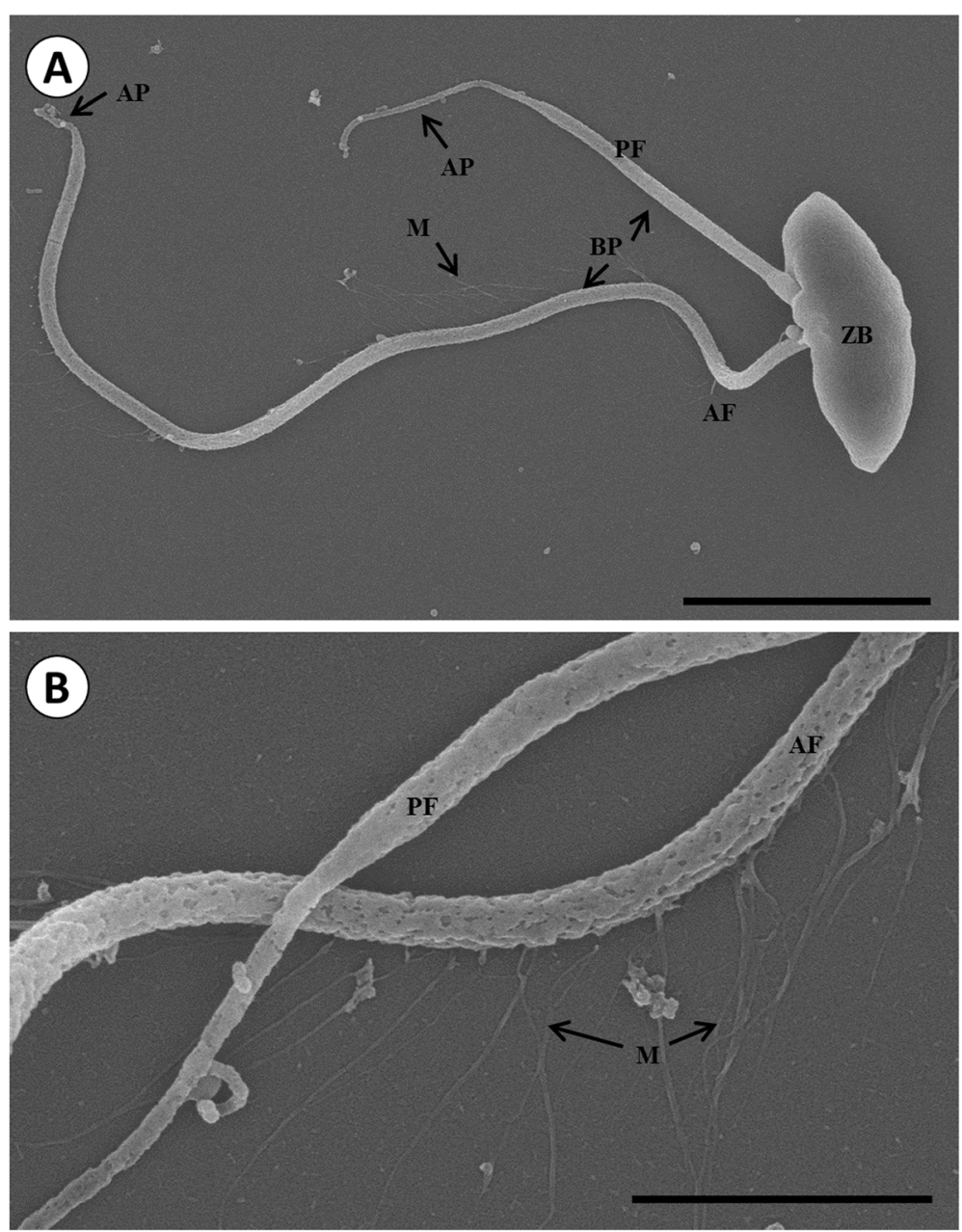

Fig. 2 Scanning electron micrograph of $P$. olseni zoospore (a) and tinsel (mastigonemes, M) (b). A zoospore with the anterior flagellum (AF) and posterior flagellum (PF). The flagellum is rooted in the zoospore body (ZB). The flagellum is divided into two parts; the basal portion (BP) and an apical portion (AP). Unilateral array of tinsels on the anterior flagellum (M). Scale bar $=2 \mu \mathrm{m}(\mathbf{a})$, Scale bar $=1 \mu \mathrm{m}(\mathbf{b})$ 